\title{
Everyone already has their community beyond the screen: reconceptualizing online learning and expanding boundaries
}

\section{Kyungmee Lee ${ }^{1}$ (D)}

Published online: 6 July 2018

(C) The Author(s) 2018

\begin{abstract}
A constructivist learning paradigm emphasises authenticity as a required condition for learning. However, the design of an online learning environment is ultimately separate from learners' real-life environments, it is inevitably challenging to make online learning authentic. In this article, the author aims to propose an alternative way of conceptualizing online learning and its boundaries, based on a double-layered Community of Practice model as a means to facilitate authentically constructivist online learning. The model conceptualizes online learning as interlinked processes of participation and socialization in multiple communities across online- and offline-"layers" of learners' lives. The model guides online course designers in expanding the perceived boundaries of the course environments they design to include learners' offline learning contexts. Instead of having an exclusive focus on providing learners with constructivist learning opportunities within a non-authentic course environment, the model suggests helping learners to engage in more personalized social learning activities situated in their everyday lives. The paper presents data from a series of case studies drawn from the author's work that has examined students' learning experiences in different kinds of online courses, unpacking and answering the central question of what authentically constructivist online learning looks like in each case. With a more holistic conceptualization of online learning, which recognizes and supports online learners' simultaneous presence across internal and external communities, instructional designers may be able to facilitate learners' more authentically constructivist learning experiences.
\end{abstract}

Keywords Authentically constructivist learning - Community of practice - Online learning $\cdot$ Online course design $\cdot$ Double-layered CoP model

\section{Introduction}

Imagine oneself in conversation with a student who has strong beliefs about what learning means. She positions herself humbly, saying "based on my experiences", but her position is firm: to her, learning means acquiring new (to her) knowledge through watching online

Kyungmee Lee

k.lee23@lancaster.ac.uk

1 The Department of Educational Research, Lancaster University, County South, Lancaster, Lancashire LA1 4YD, UK 
lectures, reading guidebooks, and writing exams; it should be an individual practice and a solo performance, with some support from tutors and institutions. Perhaps, a researcher would immediately start to subconsciously question the validity of this student's experiences. However, what if this student were a successful recent graduate of an online program at an open university? Would there be a temptation to question the quality of the program, or the legitimacy of the university, the extent to which the knowledge learned was meaningful, and the validity of the assessments? What if she continued to list all of the meaningful things that she had learned and achieved from enrolling in the program; emphasising that she gained great satisfaction from completing it, and that it made positive changes in her life? At what point would this student be taken seriously-not as some wellmeaning but naïve ingénue, but as someone whose epistemological beliefs merit respect?

In a "social constructivist learning paradigm" (Anderson and Dron 2011; Harasim 2012), learning is defined as a social practice that involves a group of students actively participating in collaborative knowledge construction processes (Scardamalia and Bereiter 1994; 2014). Instructional theories and strategies developed and utilized within this regime focus extensively on enabling student-to-student interaction and on building learner communities online (Garrison and Arbaugh 2007; Stahl, et al. 2006; Swan 2002, 2009; Thompson and MacDonald 2005). In this context, where notions of "collaborative" learning and learning "community" have gained substantial legitimacy, other beliefs about meaningful learning (including the one of the student above, who actually participated in this study), are likely to be severely criticised or, at best, simply neglected (Lee 2017; 2018). These matters are not merely concerns for theorists, but have influence and consequences for practice in higher education (HE). Many researchers in online higher education have been striving to implement constructivist instructional strategies, aiming to increase both asynchronous and synchronous communications among distance learners (e.g., Gutierrez-Santiuste and Gallego-Arrufat 2015; Ruey 2010; Smyth 2011). Do such initiatives serve students of the type indicated above?

It is not difficult to notice a gap between the accepted theoretical ideas of effective online learning and actual pedagogical practices in most online HE institutions, including those in many open universities (Lee 2018). Petraglia (1998) argued that instructional designers (or educational technologists) had tended to overlook the original, fundamental, epistemological ideas of constructivism. This is done by "pre-authenticating learning environments or "creating environments that are predetermined to reflect the real world," although constructivism denies precisely the notions of pre-authentication or pre-determination (p. 53). Constructivist learning theories (e.g., situated learning theory) emphasise authenticity as a required condition for learning. However, when the design of an online learning environment is ultimately separate from learners' real-life environments, it is inevitably challenging to make online learning authentic. An alternative way of conceptualizing online learning and its boundaries based on a double-layered Community of Practice (CoP) model is proposed in this article that, hopefully, will enable more $a u$ thentically constructivist learning online.

This article briefly discusses the concept of CoP (and the double-layered CoP model) and establishes the difficulties encountered in developing sustainable online CoPs. Much of this discussion is contextualized in the scholarship of teacher education. Secondly, a series of case studies examining students' learning experiences in different kinds of online courses is presented, unpacking and answering the central question of what authentically constructivist online learning can be. It is argued that a more holistic conceptualization of online learning encompassing online learners' experiences and interactions both within and outside of courses will result in more authentically constructivist learning experiences. 


\section{Communities of Practice}

The concept of $\mathrm{CoP}$ is fundamentally based on situated learning theory that describes learning through active participation in shared practices of social communities (Lave and Wenger 1991). Unlike many classroom-based learning activities focusing on knowledge separately from the contexts in which it was originally developed and applied, situated learning theory suggests that knowledge needs to be presented and obtained in authentic contexts, and that learning occurs somewhat unintentionally through social activities embedded in those contexts (see Brown et al. 1989). Although Lave and Wenger's (1991) original anthropological monograph did not provide a clear definition of $\mathrm{CoP}$, it vividly explained how newcomers are socialized in existing communities, and how they master particular skills and knowledge through a process of 'legitimate peripheral participation'. This new approach to understanding professional learning was further developed in Wenger's subsequent work (1998) arguing that CoPs consist of groups of people sharing common interests and desires to participate in and contribute to the practices of their communities at work, school or even at home.

Wenger (1998) defined CoP as "groups of people who share a concern, a set of problems, or a passion about a topic and who deepen their knowledge and expertise in this area by interacting on an ongoing basis" (p. 4). Three structural indicators of CoP were also proposed; mutual engagement, joint enterprise, and shared repertories. Those were more clearly defined and re-termed as domain, community, and practice later (Wenger et al. 2002). All CoPs have a shared domain of knowledge, which creates common ground, inspires members to participate, and guides their learning. In pursuing their domain interest, members engage in joint activities and interactions to share ideas, and build relationships enabling learning from each other. CoP is distinguished from communities of interest or communities of learning that do not require the "practice" element. With the fast recognition of the conceptual merit of the $\mathrm{CoP}$, there has been an increasing focus on the deliberate development of CoPs in real-life educational contexts-both in informal and formal settings (including virtual environments).

\section{A double-layed CoP model}

The double-layered CoP model was originally developed by incorporating $\mathrm{CoP}$ principles into an online teacher education course addressing the divisions between teachers' online learning and their classroom teaching (Lee and Brett 2013, 2015). That model conceptualizes teachers' online learning as interlinked processes of participation and socialization in multiple communities across online- and offline-"layers" of teachers' lives.

Figure 1 illustrates how the double-layered $\mathrm{CoP}$ module can be operationalized in the context of online course design and teaching. First, an online course itself is nurtured and developed into an internal CoP through four interdependent learning phases; i.e., course preparation, foundation building, interactive learning, and knowledge transfer. During the first phase, 'course preparation' before the course starts, the value of learning in CoPs is clearly emphasized and the structure of the course (that is, a double-layered CoP) is explicitly explained to participant teachers. During the second phase, 'foundation building', introductory CoP readings are provided with a discussion question: "Is CoP a useful concept for learning?" Participant teachers develop a conceptual understanding of CoPs and conceptualize the course as an internal $\mathrm{CoP}$ to be developed to support their authentic 


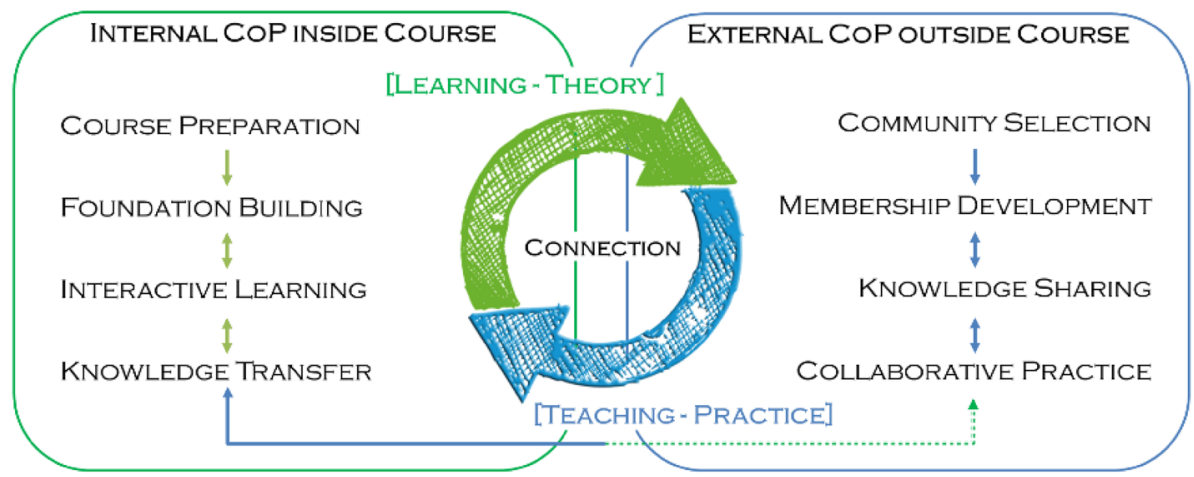

Fig. 1 An illustration of the double-layered CoP model (Lee and Brett 2015)

professional learning situated in their real-life environments outside the course (i.e., external CoPs).

Each teacher selects an existing group in their teaching context (e.g., colleagues in their school) and develops it into an external CoP, by applying the CoP principles. The aim is to encourage each teacher to take the lead in building a good CoP in their school, one which would endure for longer than the internal course $\mathrm{CoP}$. This rather challenging task needs to be structured as small sub-tasks in a sequence; i.e., community selection, membership development, knowledge sharing, and collaborative practice (Fig. 1). Teachers write CoP journal entries reflecting on their experiences developing the external $\mathrm{CoP}$ (and becoming a core member of the $\mathrm{CoP}$ ) and in connecting course ideas to practice in that CoP. The course description also explicitly states: "bring your external CoP stories into your online course $\mathrm{CoP}$ and bring your course knowledge back to your external CoP".

The third phase, 'interactive learning', offers diverse collaboration opportunities; online discussions and a group project. All collaborations focus on linking the course CoP to the external CoPs to facilitate 'knowledge transfer' between the two. This is both the last learning phase of the model and the ultimate goal of the course-aiming to make actual changes in participant teachers' professional practice. The model thus enables online course designers to expand the perceived boundaries of environments they design to incorporate teachers' offline learning contexts, including teachers' professional practices. Instead of having an exclusive focus on building a single community within an online course, the model encourages each teacher to nurture and improve their interactions with members of their school communities, of which most teachers are already active members (Osterman 2000). That is, the model helps teachers to engage in more personalized social learning activities situated in their everyday lives.

How are the pedagogical ideas provided by the double-layered $\mathrm{CoP}$ model relevant to students like the one described above preferring individual learning? In what ways might these ideas be usefully mobilized to reduce the gap between social constructivist learning theories and actual online learning practices? In fact, this particular student's online learning experience, effectively illustrates how important it is to expand the perceived boundaries of the learning environment and to count socialization experiences offline as an integral part of the online learning processes. This new double-layered $\mathrm{CoP}$ conceptualization allows developing a clearer understanding of how truly social, situated, authentic- 
that is, constructivist-online learning experiences might actually occur, reflecting multiple legitimate views on online learning.

\section{Previous studies of developing online teacher CoPs}

Although teacher CoPs have a variety of forms, members and activities, all need these structural elements:

[T]he well-being of students must be central. According to this criterion, not all gatherings of teachers, even those in which teachers offer each other fellowship and support, constitute professional community: Teachers who gather to read mystery novels, even if they do so in the school library, would not meet our definition of professional community. (Grossman et al. 2001, p. 951)

This criterion clearly distinguishes teacher CoPs from other educational communities such as communities of learners, communities of interests and communities of teachers (see Barab and Duffy 2000). Furthermore, it tends to be rather difficult to expect teachers to spontaneously build a CoP without any institutional support. Even though, theoretically, teacher CoPs are often understood to be "open and voluntary gatherings of individuals concerned with the general practice of teaching or specialist disciplines or areas of interest" (Lloyd and Duncan-Howell 2010, p. 61), actually forming a CoP can be highly demanding for busy teachers (Chai and Merry 2006).

There have been various studies to investigate the design principles effective for online teacher communities (Liu 2012; Lloyd and Cochrane 2006; Wood 2007). One of the first large-scale research projects to build an online teacher education environment incorporating CoP principles was TAPPED IN (see Farooq et al. 2007; Schlager et al. 2002). The project focused on developing an environment that enabled (i) teachers to participate in self-motivated development activities in their professional contexts, (ii) educational organizations to cooperate with each other and develop larger $\mathrm{CoPs}$, and (iii) education agencies to organise and host online $\mathrm{CoP}$ activities, including online seminars or courses. From its beginnings in 1997, more than 50 organizations and 150,000 education professionals participated in and/or organised various activities in the environment and TAPPED $I N$ itself was regarded as a large online education community of practice. However, after the funding for this initiative ended in 2008, it was not successful despite voluntary efforts to sustain it.

Another example of a large-scale online teacher $\mathrm{CoP}$ project is the Florida Online Reading Professional Development Initiative (see Zygouris-Coe and Swan 2010). The project aims to develop a sustainable, state-wide $\mathrm{CoP}$ for educators specializing in reading education online. Despite its success in building collaboration and sharing knowledge, the developers conclude that "[d]eveloping and sustaining an effective online learning community can be challenging even in the midst of an era of much technological advancement. Developing and sustaining an effective large-scale online community is even more challenging' (p. 130). The lesson from projects of this nature is that sustainable CoPs require all three structural conditions of domain, community, and practice; i.e., mutual interests, joint enterprises, and shared resources, to facilitate and maintain continuous interaction among members (Wenger 1998). The TAPPED IN and Florida Online Reading Professional Development Initiative demonstrate that sustaining teacher CoPs is generally more difficult than creating them. 
There are also a few studies focusing on developing teacher communities nested inside online teacher education courses. For example, Slaouti (2007) documents attempts to build a CoP in a course environment through deliberately facilitating teachers' interactive learning and reflective teaching, while Hramiak's (2010) work has a similar emphasis, encouraging teachers to share accounts of their teaching practices. However, both projects were unable to sustain their CoPs after the courses ended. Tsai's (2011) study, by contrast, exclusively focuses on how to sustain in-service teachers' participation in online CoPs, built through their preservice teacher education courses. Tsai suggests that computermediated communication tools facilitate teachers' ongoing discussions, and that online CoPs have great potential to connect teachers' formal educational experiences with their teaching practices. Nevertheless, Tsai acknowledges participation tends to be mainly shaped by course activities and requirements; so the sustainability of the CoP remains questionable.

\section{Case studies: learner experiences in three online courses}

Three distance learners' narratives, each from a different online course, will be used to illustrate the importance of expanding the conceptual boundaries of online learning. In aiming to answer the question of what authentically constructivist online learning can be, the three learners are purposely selected from three different case studies conducted by the author between 2013 and 2017 (Lee and Brett 2015; Lee et al. under review). This purposive case selection was made based on two inter-related grounds, following a two-stage procedure. Three online courses that are very different from each other were first selected. Those courses varied considerably in the extent to which social constructivist learning theories (i.e., $\mathrm{CoP}$ ) were applied in practice. The first course was not designed using the principles of CoP. The second course was designed based on the principles of CoP, but in practice is exclusively focused on building a $\mathrm{CoP}$ within the course environment. The third course was designed specifically using the double-layered CoP model, with serious efforts to build sustainable offline CoPs outside the course. Those courses are also different-in terms of the degrees being awarded, the disciplines being studied, and the cultural context.

Secondly, one student case from each of the selected three online courses was chosen. The three chosen students expressed distinctive views on online learning based on their experiences in the three different online courses. At the same time, however, their online learning experiences and perspectives are broadly representative among their classmates and cohort members. The first case draws on accounts from Sumi, a recent graduate from an online management program at an open university, whose view on learning is seemingly individualistic. Sumi is the student whose beliefs were summarised at the beginning of this article. The second case features Oliver, a recent graduate from an online doctoral program at a department of educational research, whose views on learning are considerably aligned with those of constructivist learning theorists. The third case examines Jane, who earned her Master's degree in education from a campus-based university offering a range of online courses. Her conceptualization of meaningful learning is also in line with some social constructivist learning theorists, but it differs from Oliver's in ways important for the argument in this paper. Despite the differences, there are shared characteristics among the three students: all are married adults with children and all work as educational practitioners. 


\section{Case 1: Sumi (BA in Human Resources Development)}

Sumi, who is an educational program coordinator, successfully completed her undergraduate program at an open university in South Korea. All graduating students at the program in 2015 were invited to participate in a case study examining adult students' online learning experiences. Sumi was one of ten participants (Lee et al. under review). The online courses they completed did not offer any structured collaborative learning opportunities. Although each course did have a discussion forum, in which some discussion topics and resources were listed and contribution to online discussions was encouraged, the average participation rate was low. More than 100 students were in each course. Consequently, most of the interviewees reported a lack of social presence: a sense of knowing their peers and tutors (Gunawardena 1995). These students had struggled alone to learn "what to do" and "how to do" in a new and challenging "online" learning environment. Sumi said, "My first semester was a real struggle, with a massive level of uncertainty and anxiety_-so I had to take time off from my study, and many of us in my cohort did quit anyway."

After a couple of years, Sumi returned to the same program and completed her study. She recalled that "The second time was much easier because I learnt a lot from the previous failure." The interview accounts from these students suggest that they had established unique learning habits, suitable for each of their life-styles and gradually integrated them into their wider life routines by trial and error. Without having a sense of community at the course level, these students had naturally focused on developing rather individualistic study habits and "know-how", and had become independent learners. In Sumi's case, she set up daily routines of waking up in the early morning and, for about an hour, watching one online lecture and writing notes, which she would study during exam periods. Once she had familiarised herself with that routine and completed her second semester, her learning habits remained the same throughout the next five years of study. For her (and most other students in her program), online discussions or any other social interactions within the courses became considered as "distractions" that would disturb established learning routines. Sumi said:

There is enough knowledge in textbooks and I can read them alone. Listening to professors' explanations presented with useful examples in online lectures help me better understand knowledge. Any challenging idea... I eventually get it by repeating that process, then it is really fun to learn... Of course, I know, I can ask a question on the course website and I know some of my classmates or tutors may answer. But, it is not really necessary. I can just google it and search for other materials online. There are tons of resources developed by experts anyway and this is quicker.

As a quasi-independent learner, Sumi and the other nine students featured in the case study successfully earned their university degrees. Sumi repeatedly emphasised how much she likes to learn new knowledge and to use it in her work space where she meets close colleagues who are also studying at the open university. The tone of the narrative offered by this staunchly independent learner suddenly shifted when these matters were discussed. Although social interactions in her online courses were limited and not desired, Sumi had established an effective learning community outside those courses. All of her "friends" in that "study group" (her vocabulary) were studying different subjects but in the same work place, and they had provided each other with endless emotional and social support-she said "we learned, worked, and almost lived together during the past several years." 
Sometimes, Sumi added, listening to what her friends were studying helped her understand her subject areas better and also to work better. She elaborated:

In reality, open university degrees tend to be recognized as something inferior to the ones of traditional universities, however, the best value of being an open university student for me was to learn how to be an independent learner and developed my lifelong friendship. I am very proud of myself and my degree from open university.

Sumi believes that it was being able to learn in "her way" that enabled her to pursue challenging courses and develop friendships while also working and raising a child. Sumi's course experiences seem neither social nor authentic, but relating them to her work and sharing them with colleagues added 'social' and substantially 'constructivist' aspects to her online course experiences. This theme was echoed by the other nine interviewees. For example, Juhan met some like-minded people in his social club, with whom he shared and discussed diverse ideas generated by his study. Some interviewees had their partners, siblings, or friends eager to learn new knowledge with various interests (so-called lifelong learners). Mira was able to talk and often prepare for exams with her "supporters". To Hansu, it was his two high school daughters motivating him to continue and complete his study. Although these offline communities or groups may not be precisely defined as CoPs, learning in an original (social) constructivist sense is processes of participation and socialization in social communities and becoming a legitimate member of society. The fact that all ten adult learners clearly explained social-relational aspects of their online learning, which ultimately transformed who they are in those offline relationships, needs to be included in the conceptualization of online learning.

\section{Case 2: Oliver (PhD in Educational Research)}

Oliver is an educational developer planning and organising faculty development programs at a university in the United Kingdom (UK). Oliver was one of thirteen doctoral students who participated in a case study on online doctoral students' learning experiences. All invited students were close to completing their theses in the online program offered by a research-intensive university in the UK which is, in rhetoric and by design, social constructivist and community-oriented. The program consists of two academic phases: in Part 1 , approximately 25 doctoral students, who are all in-service educational professionals, enter the program at the same time and take six online courses together for the first 2 years. All courses are very carefully designed to foster a strong sense of social presence among participants, and to build a supportive CoP among the cohort.

This social learning process is effectively facilitated by a range of collaborative activities (e.g., group discussions, presentations, peer-reviews of draft assignments), and by one annual meeting when all cohort members come to campus and participate in face-toface sessions for 4 days. Subsequently, students move to Part 2, in which they independently work on their thesis projects with some faculty guidance for a period of two to three years. Oliver describes his experiences in Part 1 as:

[T]he sense of community aspect was great. I think we all benefited from learning as a group and we had a lot of conversations around the value of learning together in a group, because it really helped to keep you focused, keep you engaged. So that was a real bonus... we had the residential in the first year and after the residential I think we all really bonded as a group, and that was a really pivotal moment, going through module one [the first module in the program]. But then my subsequent modules 
were... you kind of knew who everyone was so you could just get straight on with answering the discussions and the content and that kind of thing... I started to feel more confident with what I was dealing with and was making more informed decisions.

During Part 1, Oliver and his cohort had effectively formed a $\mathrm{CoP}$ where they could support each other doing doctoral studies as part-timers. Like Sumi, Oliver suggests he had found particular ways of learning, albeit ones more recognisably 'social' in character, and that doing so had made him feel more confident about his subsequent Part 1 courses. However, Oliver's experiences in Part 2 were quite different:

It's definitely a very different experience... because our group really enjoyed both residentials, we organised a residential earlier on in the third year. So during the transition to Part 2, about six of us went to [the university], some of us are from overseas. We sort of self-organised a little program... Because we felt that we really wanted to maintain that sense of community and it was actually really important to us. So we tried to extend it as long as we could, and then we all went off after the residential... the community aspect just sort of dissipated really... As soon as you get into Part 2, it's really difficult to maintain those community ties. We'd set up a little sort of learning group... A lot of people had used Facebook in the past and we tried to keep it going and it just died really as everyone gets immersed in their Part 2.

It may be worthwhile to add another point made by John, a member of Oliver's cohort in Singapore:

I know my cohort had like another residential, which I heard about after the fact that they had organised their own. So some parts of [the cohort] still have a sense of community. I don't feel [and have never felt] the sense of community in my cohort... there's an inner group and the outer group. So some groups are going to form. And I mean I'm fine with that. There's no way I was going to [the university] if I really didn't have to. Not that I don't like it. But I like to visit and I like hanging out with [tutors], but it's just too expensive. For me it's just a big expensive trip, going to the UK.

This case illustrates three points. First, it may be very difficult to build a "strong" CoP in fully online courses. Conversely, the usefulness of campus residentials for increasing a sense of community, which was emphasised by all 13 interviewees, suggests the challenging nature of developing that sense of community without face-to-face interaction. Yet, those face-to-face interactions seem to be too costly for some students, including John. Second, once built, it may be still more difficult to make the CoP equally beneficial. Unlike Oliver who belongs to the "inner group" (John's vocabulary), John's collaborative learning on Part 1 was a consistent struggle, resulting in him being in an "outer group" who were not invited to the third residential self-organised by some peers. Although only three interviewees including John shared negative opinions about collaborative learning, it certainly provides important lessons about building course CoPs. Third, it seems even more difficult to maintain the CoP after a formal course period. Even Oliver found it very challenging to maintain the frequent contacts with his cohort members during Part 2. The cohort CoP, which had been carefully built throughout Part 1 as a result of the pedagogical efforts of tutors, students, and program administrators, fell into disrepair when there was no "imposed" shared domain and practice. 
Unfortunately, Oliver and the other students still needed social support. Indeed, the fact these students had previously experienced support routinely meant that they felt its absence more keenly. The sense of an "extinction" of the cohort CoP in Part 2 rather distressed and hindered Oliver (and other students), who suddenly felt left alone and newly asked to be independent. The literature on online CoPs suggests that it is sadly inevitable most such online communities will cease to exist. This case offers evidence about the importance of building sustainable CoPs not only within the online course environment but also offline, outside that environment.

\section{Case 3: Jane (MA in Education)}

Jane is a part-time Master's student who is a secondary school teacher in Canada. She was one of seventeen student-teacher participants in a 12-week-long online course on educational applications of technologies, which was designed using the double-layered CoP model. Her Masters program admits about 100 students each year. A large number of courses are offered both online and face-to-face and students choose and take any eight courses from those available and conduct a small-scale thesis project. The seventeen students who agreed to participate in this study all voluntarily selected this specific online course offering guided activities assisting students to search for existing communities in their own professional contexts, possibly ones of which they are already members, and to develop it into a good (or better) CoP. Students were encouraged to build and participate in both an internal (course) $\mathrm{CoP}$ and an external (professional) $\mathrm{CoP}$, and to make close connections between each. The course focused on educational application of technologies as the course description explicitly stated:

This will be a discussion-based course using online readings and resources in an asynchronous conferencing format. Collaborative learning in CoPs, is the focus for our course. During this course period, you will be participating in two different teachers' CoPs: (1) the first developed in the course environment by the whole class... (2) You may search for and select the second CoP outside of the course environment... You are encouraged to reflect on that $\mathrm{CoP}$ in relation to the course CoP.

Structured tasks specifically required each student to write CoP journal entries reflecting on their experiences in developing the external CoPs and in connecting course ideas to practices in the external CoPs. Jane, in one of her first CoP entries, entitled 'community selection', said:

Without even knowing it, I have been involved in and continue to be involved in various communities related to my profession in education. However, it was quite difficult for me to recognize a $\mathrm{CoP}$ to which I belonged, as I belong to various 'communities' with shared interests (the 'domain'). However, each was missing the component of 'practice'... I have already begun to float this term 'CoP' around at work with other teachers. I think that it is actually vitally important to the teaching profession. If this is just one idea of the course, then I like where this course is headed.

Jane first set up an online space using a platform in her school, in which she and her colleagues could discuss Blended Learning (BL), one of the course's topics. For the first few weeks, this space and Jane's BL initiative attracted considerable attention from Jane's fellow teachers, and some enthusiastic participation was evident. However, Jane soon 
found it quite challenging to maintain active online conversations, and to further develop actual teaching practices out of that asynchronous format of conversations. Jane later concluded: "one specific idea I was wrestling with is the longevity of CoPs. I think that it may be difficult to sustain CoPs if there is no direct face-to-face contact." Consequently, Jane arranged face-to-face meetings, during which she and her colleagues developed actual action plans for designing and teaching various BL components. At the end of the course, she wrote:

As I write my final CoP journal, I am thinking of all the people I've worked/learned with over the past three months. At times, I felt it was too difficult to fulfill all my professional and educational responsibilities though, with the help and cooperation of my co-workers and other students in this course, I have grown deeply in my understanding of cooperative learning within CoPs... [Firstly] I believe I have been privileged to have been a part of such an enjoyable course... [Secondly] my professional $\mathrm{CoP}$ is with co-workers who are also using $\mathrm{BL}$ for the first time. Our classrooms mix face-to-face learning and online learning: a first in our school! Our [school] CoP is also a mix of online asynchronous communication and some face-toface collaboration. I think we have a thriving CoP as we rely on one another to deal with real logistical and pedagogical issues that come up on a daily basis... We have each grown in our confidence with this new teaching and learning format, we are each a bit more assured as we proceed throughout the courses we teach. I do think our CoP will continue as long as we all continue to use BL.

The online course involved all three criteria required to be considered as a $\mathrm{CoP}$ (Wenger 1998). The shared mission to develop an internal CoP became a joint enterprise that all students mutually engaged in. Students collaboratively constructed new knowledge and produced rich discussions and educational resources online (i.e., shared repertoires). Jane actively engaged with course readings and discussions, yet the more important part of her learning about BL happened in her external school CoP. Course readings provided her with a foundation for her BL initiative, while course discussions were closely linked to, and facilitated by, her school CoP experiences. The course CoP effectively supported Jane's offline learning experiences by offering guided activities to develop her school CoP and a safe space to talk (and sometimes complain) about difficult issues arose from the development process.

In fact, like Jane, who was struggling to maintain the initial enthusiasm among her colleagues, most students faced some sort of challenges while interacting with other members in their school context; e.g., a lack of shared interest and/or understanding, unequal power relationships among members, and insufficient institutional support. Sharing such challenges in the course, however, often triggered rich discussions among course participants, which resulted in various strategies to overcome the challenges. More than a half of the course participants (10 out of 17) had successful external CoP experiences including collaborative practice. The other half had somewhat limited success in developing a CoP: their professional "communities" achieved much in the areas of membership development and knowledge sharing, but often failed to established shared practice. Such results again demonstrated the challenging nature of developing a CoP. Nevertheless, all seventeen students considered their learning experiences during the course period very meaningful and unique.

A few months after the course was completed, a brief follow-up email was sent out to the students. Nine students responded that they were continuing to participate in their external professional CoPs. Jane said: 
Definitely, I have been participating in my CoP at school and continue to do so because I find it extremely helpful to collaborate with other members on certain tasks. The question we continue to address is how we can incorporate technology effectively into our classes... I love being part of my CoP and I think everyone should participate in one, especially if they are educators.

\section{Closing remarks}

Everyone has their own community, in which they naturally learn, develop, and live with other members, outside their formal educational settings. The authenticity of real-life interactions and relationships is a required condition for constructivist learning. Although Sumi's online courses did not support her social learning, she spontaneously built a strong study group with her colleagues at work where she learned and grew as an independent learner. Conversely, Oliver had enjoyed and focused on institution-driven social learning activities in his online courses. However, when the institutionalized online support finished, he soon felt left alone in his offline context without any support systems and found it challenging to become a newly independent (or sole) learner. Researchers and instructional designers need to expand their view of what constitutes the learning environment, to include distance learners' real-life situations beyond course. Rather than directing their efforts exclusively towards forming CoPs inside the online course, designers can help existing communities in learners' real-life contexts to become more supportive and sustainable CoPs. Those external CoPs can offer better situated learning opportunities. Jane's case, using the double-layered $\mathrm{CoP}$ model, illustrates an alternative way of conceptualizing online learning and expanding boundaries of our design and pedagogical practice.

The double-layered CoP model stresses three inter-related design principles that can effectively guide instructional designers' efforts to make online learning authentically constructivist. First, students need to be given learning opportunities to construct a clear theoretical understandings of $\mathrm{CoP}$; the term $\mathrm{CoP}$ should not just used as a euphonious rhetorical expression referring to any learning communities. Second, the course structure and activities need to explicitly guide students' attempt to choose and develop one of their existing communities into a supportive $\mathrm{CoP}$ using the theoretical understanding. However, this should be a student-driven process; each student is the agent of the development process of their professional $\mathrm{CoP}$ and projects their own identity as a core member of that external $\mathrm{CoP}$. This principle is particularly important given that the notion of $\mathrm{CoP}$ has been applied into organizational and institutional contexts with an increasing managerialist focus. In that process the original insight about the authenticity and spontaneity of learning in CoP has been lost or neglected (Cox 2005). Third, the challenging nature of building a $\mathrm{CoP}$ needs to be clearly shared by all course participants; the development of a course CoP can be fostered by having a shared goal of developing external CoPs and supporting each other's situated learning in the external CoPs. Those suggested principles are certainly more relevant and applicable to online course design (than face-to-face course design) considering the common characteristics of online learners; i.e., their simultaneous presence in both learning and living (working) contexts.

Acknowledgements I am grateful to both the editor as well as all anonymous reviewers for their helpful comments and useful suggestions that contributed to the present version of this article. Further, I wish to thank Brett Bligh and Clare Brett for their generous support and constructive suggestions on a previous version of this article. 


\section{Compliance with ethical standards}

Conflict of interest The authors declare that they have no conflict of interest.

Open Access This article is distributed under the terms of the Creative Commons Attribution 4.0 International License (http://creativecommons.org/licenses/by/4.0/), which permits unrestricted use, distribution, and reproduction in any medium, provided you give appropriate credit to the original author(s) and the source, provide a link to the Creative Commons license, and indicate if changes were made.

\section{References}

Anderson, T., \& Dron, J. (2011). Three generations of distance education pedagogy. International Review of Research in Open and Distance Learning, 12(3), 80-97.

Barab, S. A., \& Duffy, T. (2000). From practice fields to communities of practice. In D. Jonassen \& S. M. Land (Eds.), Theoretical foundations of learning environments (pp. 25-56). Mahwah, NJ: Lawrence Erlbaum Associates.

Brown, J. S., Collins, A., \& Duguid, P. (1989). Situated cognition and the culture of learning. Educational researcher, 18(1), 32-42.

Chai, C. S., \& Merry, R. (2006). Teachers' perceptions of teaching and learning in a knowledge-building community: An exploratory case study. Learning, Media and Technology, 31(2), 133-148.

Cox, A. (2005). What are communities of practice? A comparative review of four seminal works. Journal of Information Science, 31(6), 527-540.

Farooq, U., Schank, P., Harris, A., Fusco, J., \& Schlager, M. (2007). Sustaining a community computing infrastructure for online teacher professional development: A case study of designing Tapped In. Journal of Computer Supported Cooperative Work, 16(4-5), 397-429.

Garrison, D. R., \& Arbaugh, J. B. (2007). Researching the community of inquiry framework: Review, issues, and future directions. Internet and Higher Education, 10, 157-172.

Grossman, P., Wineburg, S., \& Woolworth, S. (2001). Toward a theory of teacher community. Teachers College Record, 103(6), 942-1012.

Gunawardena, C. N. (1995). Social presence theory and implications for interaction and collaborative learning in computer conferences. International journal of educational telecommunications, 1(2), $147-166$.

Gutierrez-Santiuste, E., \& Gallego-Arrufat, M. J. (2015). Internal structure of virtual communications in communities of inquiry in higher education: Phases, evolution and participants' satisfaction. British Journal of Educational Technology, 46(6), 1295-1311.

Hramiak, A. (2010). Online learning community development with teachers as a means of enhancing initial teacher training. Technology, Pedagogy and Education, 19(1), 47-62.

Harasim, L. (2012). Learning theory and online technology: How new technologies are transforming learning opportunities. New York, NY: Routledge Press.

Lave, J., \& Wenger, E. (1991). Situated learning. Legitimate peripheral participation. Cambridge, UK: Cambridge University Press.

Lee, K. (2017). Rethinking the accessibility of online higher education: A historical review. The Internet and Higher Education, 33, 15-23.

Lee, K. (2018). Discursive effects of a paradigm shift rhetoric in online higher education: Implications on networked learning research and practice. In N. B. Dohn, S. Cranmer, J. A. Sime, M. de Laat, \& T. Ryberg (Eds.), Networked Learning: Reflections and Challenges. New York, NY: Springer.

Lee, K., \& Brett, C. (2013). What are student inservice teachers talking about in their online Communities of Practice? Investigating student inservice teachers' experiences in a double-layered CoP. Journal of Technology and Teacher Education, 21(1), 89-118.

Lee, K., \& Brett, C. (2015). An online course design for inservice teacher professional development in a Digital Age: The effectiveness of the Double-layered CoP model. In M. L. Niess \& H. Gillow-Wiles (Eds.), Handbook of research on teacher education in the Digital Age. Hershey, PA: IGI Global

Lee, K., Choi, H., \& Cho, Y. H. (under review). Becoming a competent self: A developmental process of adult distance learning.

Liu, K. Y. (2012). A design framework for online teacher professional development communities. Asia Pacific Educational Reviews, 13, 701-711.

Lloyd, M., \& Cochrane, J. (2006). Celtic knots: Interweaving the elements of effective teacher professional development in ICT. Australian Educational Computing, 21(2), 16-19. 
Lloyd, M., \& Duncan-Howell, J. (2010). Changing the metaphor: The potential of online communities in teacher professional development. In J. Lindberg \& A. D. Olofsson (Eds.), Online learning communities and teacher professional development: Methods for improved education delivery (pp. 60-76). Hershey, PA: IGI Global.

Osterman, K. F. (2000). Students' need for belonging in the school community. Review of Educational Research, 70(3), 323-367.

Petraglia, J. (1998). The real world on a short leash: The (mis)application of constructivism to the design of educational technology. Educational Technology Research and Development, 46(3), 53-65.

Ruey, S. (2010). A case study of constructivist instructional strategies for adult online learning. British Journal of Educational Technology, 41(5), 706-720.

Scardamalia, M., \& Bereiter, C. (1994). Computer support for knowledge-building communities. Journal of the Learning Sciences, 3(3), 265-283.

Scardamalia, M., \& Bereiter, C. (2014). Knowledge building and knowledge creation: Theory, pedagogy, and technology. In K. Sawyer (Ed.), Cambridge handbook of the learning sciences (2nd ed., pp. 397-417). New York, NY: Cambridge University Press.

Schlager, M. S., Fusco, J., \& Schank, P. (2002). Evolution of an on-line education community of practice. In K. A. Renniger \& W. Schumar (Eds.), Building virtual communities: Learning and change in cyberspace (pp. 112-145). New York, NY: Cambridge University Press.

Slaouti, D. (2007). Teacher learning about online learning: Experiences of a situated approach. European Journal of Teacher Education, 30(3), 285-304.

Smyth, R. (2011). Enhancing learner-learner interaction using video communications in higher education: Implications from theorising about a new model. British Journal of Educational Technology, 42(1), 113-127.

Stahl, G., Koschmann, T., \& Suthers, D. (2006). Computer-supported collaborative learning: An historical perspective. In R. K. Sawyer (Ed.), Cambridge handbook of the learning sciences (pp. 409-426). Cambridge, UK: Cambridge University Press.

Swan, K. (2002). Building learning communities in online courses: The importance of interaction. Education, Communication \& Information, 2(1), 23-49.

Swan, K. (Ed.). (2009). Threaded discussion. Encyclopedia of Distance Learning. Kent: Ohio: Kent State University IGI Global.

Thompson, T. L., \& MacDonald, C. J. (2005). Community building, emergent design and expecting the unexpected: Creating a quality e-learning experience. Internet and Higher Education, 8(3), 233-249.

Tsai, I. (2011). Levels and patterns of participation and social interaction in an online learning community for learning to teach. Journal of Interactive Learning Research, 22(2), 191-239.

Wenger, E. (1998). Communities of practice. New York, NY: Cambridge University Press.

Wenger, E., McDermott, R., \& Snyder, W. (2002). Cultivating communities of practice: A guide to managing knowledge. Cambridge, MA: Harvard Business School Press.

Wood, D. R. (2007). Professional learning communities: Teachers, knowledge, and knowing. Theory into Practice, 46(4), 281-290.

Zygouris-Coe, V., \& Swan, B. (2010). Challenges of online teacher professional development communities: A statewide case study in the United States. In J. Lindberg \& A. D. Olofsson (Eds.), Online learning communities and teacher professional development: Methods for improved education delivery (pp. 114-133). Hershey, PA: IGI Global.

Kyungmee Lee is a Lecturer in the Department of Educational Research and a co-Director of the Centre for Technology Enhanced Learning at Lancaster University. 